\title{
Bioactive Components in Oat and Barley Grain as a Promising Breeding Trend for Functional Food Production
}

\author{
Natalia A. Shvachko (D), Igor G. Loskutov*, Tatyana V. Semilet, Vitaliy S. Popov (D, Olga N. Kovaleva \\ and Alexei V. Konarev
}

check for updates

Citation: Shvachko, N.A.; Loskutov, I.G.; Semilet, T.V.; Popov, V.S.;

Kovaleva, O.N.; Konarev, A.V.

Bioactive Components in Oat and

Barley Grain as a Promising Breeding Trend for Functional Food Production. Molecules 2021, 26, 2260. https:// doi.org/10.3390/molecules 26082260

Academic Editor: María

Roca López-Cepero

Received: 10 March 2021

Accepted: 9 April 2021

Published: 14 April 2021

Publisher's Note: MDPI stays neutral with regard to jurisdictional claims in published maps and institutional affiliations.

Copyright: (c) 2021 by the authors. Licensee MDPI, Basel, Switzerland. This article is an open access article distributed under the terms and conditions of the Creative Commons Attribution (CC BY) license (https:// creativecommons.org/licenses/by/ $4.0 /)$.
Federal Research Center, the N.I. Vavilov All-Russian Institute of Plant Genetic Resources (VIR), 42-44 Bolshaya Morskaya Street, 190000 St. Petersburg, Russia; n.shvachko@vir.nw.ru (N.A.S.); t.semilet@vir.nw.ru (T.V.S.); v.popov@vir.nw.ru (V.S.P.); o.kovaleva@vir.nw.ru (O.N.K.); a.konarev@vir.nw.ru (A.V.K.)

* Correspondence: i.loskutov@vir.nw.ru

Abstract: Cereal crops, such as oats and barley, possess a number of valuable properties that meet the requirements for functional diet components. This review summarized the available information about bioactive compounds of oat and barley grain. The results of studying the structure and physicochemical properties of the cell wall polysaccharides of barley and oat are presented. The main components of the flavonoids formation pathway are shown and data, concerning anthocyanins biosynthesis in various barley tissues, are discussed. Moreover, we analyzed the available information about structural and regulatory genes of anthocyanin biosynthesis in Hordeum vulgare L. genome, including $\beta$-glucan biosynthesis genes in Avena sativa L species. However, there is not enough knowledge about the genes responsible for biosynthesis of $\beta$-glucans and corresponding enzymes and plant polyphenols. The review also covers contemporary studies about collections of oat and barley genetic resources held by the N.I. Vavilov All-Russian Institute of Plant Genetic Resources (VIR). This review intended to provide information on the processes of biosynthesis of biologically active compounds in cereals that will promote further researches devoted to transcription factors controlling expression of structural genes and their role in other physiological processes in higher plants. Found achievements will allow breeders to create new highly productive varieties with the desirable properties.

Keywords: $\beta$-glucans; polysaccharides; flavonoids; anthocyanins; antioxidants; biological role of pigments; gene families

\section{Introduction}

Functional food products (FFPs) are gaining more and more popularity on the contemporary healthy food market, since they contain high levels of functional food ingredients (FFIs) which continuous consumption reduces the risks of diseases and metabolic disorders [1]. Such products are intended to be consumed systematically with meals by all age groups of the healthy population. The size of the world's FFP market in 2018 was estimated at 161.49 billion U.S. dollars, and there are prognoses that it will reach 275.77 billion U.S. dollars by 2025 [2]. Major components of FFPs are three groups of bioactive compounds: prebiotics, probiotics and symbiotics. FFIs are considered to include soluble and insoluble dietary fibers, vitamins, minerals, essential amino acids, unsaturated fatty acids including omega-3 and omega-6, phytosterols, polyols, conjugated isomers of linolenic acid, phospholipids, sphingolipids, and secondary plant compounds (flavonoids, carotenoids, lycopene, etc.) [3,4]. The following basic criteria are used to recognize a product as functional: it should contain only natural substances; it may and must be part of the daily or long-term diet; it should produce a targeted effect on various functions of an organism and possess curative or prophylactic properties. The FFI content in FFPs should not be less than $15 \%$ of the daily physiological requirement calculated for one serving of the product $[5,6]$. 
Unlike dietary supplements, FFPs are not served as capsules, tablets or powders; a health-friendly ingredient is incorporated directly in the composition of traditional foods at physiological concentrations. Functional foods are conceptualized as food products that underwent elimination, enrichment or substitution in their composition of nutrients (nutritive components, macro- or micronutrients) and bioactive compounds [7]. The ancient aphorism "Let thy food be thy medicine and medicine be thy food", ascribed to Hippocrates of Kos, still remains vital. The concept opens wide perspectives for the food industry in the context of developing new products with added nutritional value that will be able to contribute to human health [8]. The monitoring performed by healthcare agencies in Russia to assess the population's diet across different social groups according to their income showed that: (1) a protein deficiency from 15 to $20 \%$ of the dietary reference intake was observed among the population groups with low income; (2) a deficiency in the polyunsaturated fatty acids (PUFA) omega-3 and omega- 6 under an excessive intake of hard animal fat was found in all population groups; (3) an expressed deficiency in vitamins was typical for more than half of the population, especially in vitamin C (by 70$90 \%)$, the B group and folic acid (60-80\%), and $\beta$-carotene (40-60\%); (4) the consumption of cellulose and pectin was almost twice less than the optimal levels; (5) mineral and micronutrient deficiencies were discovered, including $20-55 \%$ in iron, calcium, fluorine, selenium, iodine, etc. [9]. In modern interpretation, considering the adopted standards and technical regulations, functional nutrition is the most important element of healthy food, which is duly recorded in regulatory and legal acts. The strategy of food quality improvement adopted in the Russian Federation until 2030 posed as one of the major objectives the provision of safe and high-quality food products to the population in volumes and assortments needed for an active and healthy lifestyle. The raw produce used for FFP usually requires special agricultural practices that must ensure appropriate safety and quality indicators. High production technologies are applied, with ecologically clean and genetically non-modified material [10]. The FFP consumer market is formed with $50-65 \%$ of milk products for functional uses, $9-10 \%$ of cereal and bakery products, $3-5 \%$ of specialized drinks, and $20-25 \%$ of other foodstuffs [3]. Cereal crop products, such as bakery and flour confectionary goods, are a promising target for modifications that shape functional properties in food [11].

Naked oats and barley hold particular promise for a variety of FFP, such as flat and tin bread, biscuits, extruded snacks and cereals. Barley bread made from whole-grain flour in various proportions improves glucose tolerance and lowers LDL cholesterol [12]. The growing demand for healthy foods is driving the use of sprouted grains to make functional flour. In a study [13], the conditions of barley grain germination were optimized in order to produce flour with high nutritional and biofunctional properties. Sprouting was shown to significantly increase the content of vitamins $B_{1}, B_{2}$ and $C$, as well as proteins, while the content of fats, carbohydrates, fiber and $\beta$-glucans decreased. Total phenolic compounds, $\gamma$-aminobutyric acid, and antioxidant activity increased from 2 to 4 times. The study showed that germination at $16{ }^{\circ} \mathrm{C}$ for 3-5 days was the optimal process for producing nutritious and functional barley flour. Under these conditions, sprouts retained $87 \%$ of the initial $\beta$-glucan content, while the levels of ascorbic acid, riboflavin, phenolics, and GABA were 1.4-2.5 times higher than those in non-sprouted grain. Of interest is the work on the use of whole-grain oat and barley for preparing functional drinks, including vegetable milk. Such drinks are rich in vitamins of the B group, complex carbohydrates (starch and non-starch polysaccharides), and minerals. Whole grain used in beverages also contains a large number of various phenolic compounds with antioxidant activity [4]. Supplementing the diet with whole oat grains, rich in $\beta$-glucans and arabinoxylans, protects against cardiovascular diseases, type II diabetes, obesity, and some cancers. In a number of countries, such as Finland, the UK or the USA, oat grains have long been used in a gluten-free diet $[8,14]$.

Currently, there are numerous options for the use of $\beta$-glucans in food as FFI. They are added to a wide variety of foods, such as baked goods and pasta, muffins, cakes, muesli, 
dairy products, soups, sauces, drinks, low-fat milk and meat products. At the same time, they have been found to affect the characteristics of food products, in particular, their water absorption capacity, texture, and appearance. By replacing some of the fats in cheeses with $\beta$-glucans, it was possible to obtain a softer structure, with a lower melting point and good organoleptic characteristics [15]. Due to its ability to mimic the properties of fats, oat fiber is one of the most effective substitutes to obtain lean meat products, such as beef patties and lean sausages. Breads with oat flavor or taste are extremely popular with customers. The content of oat in bread can reach $50 \%$. With its addition, one can make both wheat bread and rye bread, or all kinds of baked goods. Using whole-grain oat flour obtained from nontoxic oat varieties (cvs. 'Argamak', 'Rhianon' and 'Pushkinsky golozerny'), technologies were developed for preparing semifinished profiteroles, wafers and gingerbread products. Foods prepared without sucrose and wheat flour can be recommended for the diet of diabetic and celiac patients. Oat milling products added to bread contribute to an increase in the moisture content, which helps to preserve the freshness of the bread, slowing down the hardening process. This is accomplished by adding high-fiber products, such as bran flour, or pregelatinized oat products $[16,17]$. Oat-based breakfast cereals are also quite popular on the market. It has been found that the addition of $20 \%$ oat $\beta$-glucan to the flakes promotes the growth and development of health-friendly intestinal microflora [18-20].

Thus, a comparative analysis of a wide range of biochemical characteristics of oats and barley and a study of the molecular genetic mechanisms regulating the biosynthesis of $\beta$ glucans, plant polyphenols and other bioactive compounds are of fundamental importance for the development of new cultivars and their further use in breeding practice aimed at obtaining functional food products. The review summarizes information on bioactive compounds in oat and barley grain. The data on regulatory and structural genes of anthocyanin biosynthesis in Hordeum vulgare L. and $\beta$-glucan biosynthesis in Avena sativa L. are analyzed. The review presents modern case studies involving oat and barley accessions from the global plant genetic resources collection of the N.I. Vavilov All-Russian Institute of Plant Genetic Resources (VIR).

\section{Bioactive Components in Oat and Barley Grain Used in Functional Nutrition}

Cereal crops are the most popular natural source of dietary fiber. They contain unique combinations of soluble and insoluble dietary fibers, and polysaccharides, together with low-molecular-weight bioactive components. The main phytochemicals found in cereal crops are phenolic acids, flavones, phytic acid, flavonoids, coumarins, and terpenes. Grain germs are good sources of ferulic and phytic acids, glutathione, and phytosterols. In addition, cereal crop germs contain vitamins $\mathrm{E}, \mathrm{B}_{1}, \mathrm{~B}_{2}$ and $\mathrm{B}_{3}$, minerals $\mathrm{P}, \mathrm{K}, \mathrm{Mg}, \mathrm{Ca}$, $\mathrm{Zn}$ and $\mathrm{S}$, and fiber. Due to their rich nutrient content, cereal germs can be a valuable ingredient for FFP production [21].

Oat (Avena L.) and barley (Hordeum L.) are grain forage crops used for nutritional and dietary purposes. With this in view, quality indicators of grain are becoming increasingly important in the production of these crops, in addition to grain yield [22]. Oat is one of the most promising agricultural crops, since it has a number of valuable properties that meet the requirements for FFP and make it possible to use it this crop for animal feed and for medical or prophylactic purposes. Oat is traditionally regarded as a nutritious cereal crop, contains unsaturated fatty acids, sterols, basic minerals, globular proteins, and $\beta$-glucans, and is characterized by the presence of a variety of chemical compounds exhibiting antioxidant properties (tocopherols, etc.) [23-25].

Oat and barley globulins are the most balanced in amino acid composition compared with other cereals; specifically, they demonstrate high contents of essential amino acids (arginine, histidine, lysine, tryptophan, etc.) [26]. The protein content in cultivated oats ranges from 12 to $20 \%$ [27]. Oat can be grown as a protein crop. At the same time, a protein content of more than $15 \%$ was found mainly in naked oat cultivars from the VIR collection, such as 'Avel', 'Mozart', 'Numbat', 'Sibirsky golozerny', 'Persheron', 'Vladyka', and 'Gavrosh' [28]. The nutritional value of barley is also associated with the high content 
of essential amino acids in its protein. Oat grain contains a relatively high amount of oil with a valuable composition. The composition of oat oil includes essential fatty acids (FAs) indispensable for humans: unsaturated ones, such as linoleic (C18: 2, $\omega-3)$ and linolenic $(\mathrm{C} 18: 3, \omega-3)$, as well as arachidonic acid (C20:4, $\omega-6)$, together composing the so-called vitamin F [29]. An important indicator of the nutritional value of oat oil is the content of $\alpha$-linolenic acid (C18:3), a polyunsaturated omega-3 FA, which plays an important role in the prevention of atherosclerosis [30,31]. A study of the naked oat lines developed in the Volga-Vyatka region showed that the lipid content in their grain varied from 5.91 to $7.87 \%$, averaging $6.9 \pm 0.98 \%$. The main FAs of naked oat lipids in the studied lines were palmitic (15.3-17.8\%), oleic (33.5-36.7\%) and linoleic (36.2-38.7\%) acids. According to the content of oleic and linoleic acids and their ratio (1:1), lipids of the naked oat grain belong to the oleic-linoleic group of vegetable oils [32]. Another study [33] resulted in identifying lines of naked oat which received the names 'Bekas' and 'Baget' after their registration as cultivars in the State Register for Selection Achievements. The content of oleic acid in these cultivars is 36.42 and $33.49 \%$, and that of linoleic acid 35.89 and $38.37 \%$, respectively. The amount of gluten does not exceed $0.2 \mathrm{mg} / \mathrm{g}$. These cultivars can be used for functional and gluten-free food production. In one more study, the oil content varied in oat accessions from $2.7 \%$ ('Skorpion') to $8.1 \%$ ('Sibirsky golozerny'). Relatively high oil contents (over 6\%) were observed in cvs. 'Avel', 'Sibirsky golozerny', 'Persheron' and 'Vladyka': 6.6, 8.1, 15.7 and $17.3 \%$, respectively. [28] Wild oats, as a rule, have higher oil contents and the FA ratio of 18:1, generally lower than in cultivated oat (18:2 and 18:3 in FAs). In addition to conventional FAs, a certain amount of hydroxy and epoxy FAs were also present in oat oil, being mostly limited to specific classes of lipids. This study emphasizes the potential of using wild oat species in breeding programs to develop new cultivars of cultivated oat that yield oil with different FA composition and a high FA content [26,34]. Oil and lipid content was compared in wild (spp. A. fatua, A. ludoviciana, and A. sterilis, $6 \mathrm{n}$ ) and cultivated oats ( 8 covered: Astor, Lodi, Borrus, Spear, Wright, Fakir, Allyur, Argamak and 2 naked: Torch and Kynon). The oil content of cultivated oats was significantly lower with compared to wild oats, but percentage of minor lipid classes was significantly higher in cultivated accessions (Table 1) [34].

Table 1. Oil (percent of dry weight seed) and lipid content (percent of total lipid) in wild and cultivated oats samples [34].

\begin{tabular}{|c|c|c|c|c|c|c|c|c|c|}
\hline $\begin{array}{c}\text { Wild/ } \\
\text { Cultivated }\end{array}$ & $\begin{array}{c}\text { Oil } \\
\text { Content }\end{array}$ & Pl & 1,2-DAG & 1,3-DAG & FFA & $\begin{array}{l}\text { Unknown } \\
\text { Lipids }\end{array}$ & TAG1 & TAG2 & TAG \\
\hline Wild & $7.8 \pm 0.2$ & $15.4 \pm 0.6$ & $1.3 \pm 0.1$ & $1.9 \pm 0.1$ & $1.5 \pm 0.2$ & $1.0 \pm 0.1$ & $1.1 \pm 0.1$ & $0.9 \pm 0.1$ & $77.1 \pm 0.9$ \\
\hline Cultivated & $5.9 \pm 0.2$ & $16.0 \pm 0.7$ & $1.1 \pm 0.1$ & $2.3 \pm 0.1$ & $2.5 \pm 0.1$ & $1.4 \pm 0.1$ & $1.4 \pm 0.1$ & $1.1 \pm 0.0$ & $74.2 \pm 1.0$ \\
\hline$F$ value & $47.5^{* * *}$ & $0.4 \mathrm{NS}$ & $1.3 \mathrm{NS}$ & $10.6^{* *}$ & $10.2 * *$ & $4.2 *$ & $13.2^{* * *}$ & $11.0^{* *}$ & $4.3^{*}$ \\
\hline
\end{tabular}

Abbreviations: PL, polar lipids; 1,2-DAG, 1,2-diacylglycerol; 1,3-DAG, 1,3-diacylglycerol; FFA, free FAs. $F$ values are from one-way ANOVA. *** Significant at $p<0.001 ;{ }^{* *}$ significant at $p<0.01$; and * significant at $p<0.05$.

In cereals (unlike most crops), the cell walls of the grain endosperm contain very little cellulose and consist mainly of arabinoxylans and (1,3;1,4)- $\beta$-D-glucans which ratio varies significantly across different species: arabinoxylans dominate in rye and wheat, while $(1,3 ; 1,4)-\beta$-D-glucans in barley and oats $[35,36]$. Among cereal crops, the highest content (g per $100 \mathrm{~g}$ of dry weight) of $\beta$-glucan is observed in barley $(2-20 \mathrm{~g}, 65 \%$ of water-soluble fractions) and oat (3-8 g, $82 \%$ of water-soluble fractions) [37,38]. Other cereals also contain $\beta$-glucans, but in much smaller amounts: $1.1-6.2 \mathrm{~g}$ in sorghum, 1.3-2.7 $\mathrm{g}$ in rye, $0.8-1.7 \mathrm{~g}$ in maize, $0.3-1.2 \mathrm{~g}$ in triticale, $0.5-1.0 \mathrm{~g}$ in wheat, and $0.13 \mathrm{~g}$ in rice [39,40]. Beta-glucans belong to dietary fibers-high-molecular-weight carbohydrates of plant origin which produce a beneficial effect on important functions of the gastrointestinal tract and systemic processes in the human organism [41]. They help to reduce the risk of cardiovascular diseases, maintain or decrease the amount of blood cholesterol, including low-density one, mitigate the risk of hyperglycemic syndrome, improve liver functions, and reduce excessive body weight [42-46]. It is also believed that insoluble oat fiber reduces the amount of carcinogens 
in the gastrointestinal tract [47]. The U.S. Food and Drug Administration recommend a daily intake of at least $3 \mathrm{~g}$ of $\beta$-glucans from oat or barley. The European Food Safety Association has also confirmed the value of $\beta$-glucans. It has been established that the water-soluble dietary fibers $\beta$-glucans and the phenolic alkaloids avenanthramides may be included into the daily diet as FPIs [48]. Oat grains contain unique antioxidantsavenanthramides, which inhibit inflammatory processes in endothelial cells. It had shown that oat-based diets in mice reduce the risk of atherosclerosis. The processes of lipoes distribution and the becoming of atherosclerosis in mice and humans are liking, therefore oat avenanthramides are very important for the prevention of human cardiovascular diseases [49].

In recent years, there has been an increased interest in the use of antioxidants for treating or preventing diseases associated with oxidative stress [50]. Oat and barley grains are a valuable source of phytoestrogens, vitamin E, and phenolic antioxidants, possessing biological activity and capable of significantly increasing the nutritional value of products made from these grains. Among all cereal crops, $\gamma$-tocotrienol (one of the isomers of vitamin E) was found only in barley grain [51]. The presence of these and many other bioactive compounds in oats and barley makes them indispensable products both for patients suffering from various metabolic disorders and for healthy people. It should be noted that, although cereal crops are considered one of the main components of human nutrition, their oxidant activity has not been analyzed profoundly enough. In the case study of 30 different commercial breakfast cereals, it was shown that polyphenol levels in an average serving of oat-based cereals are comparable to those found in an equivalent amount of vegetables or fruits [52]. Another important group of compounds is avenanthramides. These are phenolic compounds with antioxidant, anti-inflammatory, and other types of activity.

\section{Regulatory and Structural Genes for the Biosynthesis of Anthocyanins in Barley and $\beta$-Glucans in Oats}

3.1. Regulatory and Structural Genes for Anthocyanin Biosynthesis in Hordeum Vulgare

Most researchers are attracted by the genetics of secondary metabolite biosynthesis. Their interest is evoked by the fact that plants synthesizing polyphenolic compounds are promising and, more importantly, readily available phytopreparations. It is already known that flavonoids, such as anthocyanins and proanthocyanidins, possess antioxidant and anti-inflammatory properties, and contain a large amount of vitamins (vitamin P). These valuable features make them indispensable components of a balanced human diet.

A large amount of polyphenolic compounds is found in leaves, flowers, fruits, sprouts, and cover tissues that perform protective functions [53]. Anthocyanins, along with chlorophyll and carotenoids, confer a variety of colors to fruits and seeds and produce a photoprotective effect [54]. Some of them protect plants from pathogenic microorganisms [55]. In addition to the abovementioned functions, this class of compounds provides resistance to limiting and stress factors of biotic, abiotic and anthropogenic nature, exerting a direct impact on plant development [54].

In monocotyledonous plants, flavonoid synthesis is regulated by the MBW protein complex, which includes three groups of regulatory factors: MYB, MYC (bHLH), and WD40. The MBW complex regulates the anthocyanin synthesis process, beginning with synthesis of chalcones up to the appearance of anthocyanin coloration [54] (Figure 1). 


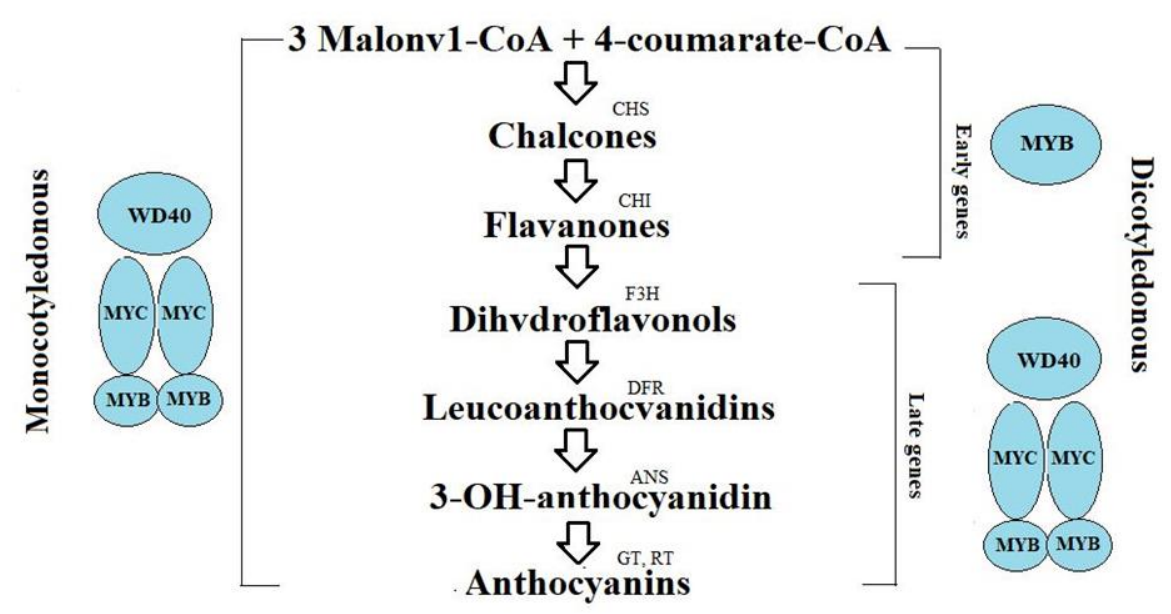

Figure 1. Biosynthesis of plant glycosides and its regulation in monocotyledonous and dicotyledonous plants [54].

Searching for and mapping structural and regulatory genes that control the pathways of biosynthesis and pigment accumulation remain a prioritized task. The main objects of research are representatives of the Poaceae Barnnhart family, widely cultivated in Russia and abroad. Among cereal grasses, the formation of flavonoids was studied in more detail in Hordeum L. [55-61], and Triticum L. [62,63], while in representatives of the genus Avena L. this aspect is still unexplored.

H. vulgare is also actively examined for molecular genetic mechanisms regulating the interaction of genes involved in the synthesis of plant polyphenols and those which expression forms a protective response to the effects of pathogenic organisms. Karre et al. demonstrated the relationship between the transcription factor HvWRKY23, which protects barley from the pathogenic Fusarium fungi, and the key CHS and DFR genes. It was found that a knockdown of HvWRKY23 reduced the expression of key genes for the biosynthesis of hydroxycinnamic acid and flavonoids. As a result, the content of secondary metabolites decreased and the number of ears afflicted by fungi increased [64]. Earlier, the same group of researchers discovered the HvCERK1 gene which expression affected the vital activity of pathogenic fungi in barley and reduced the expression level of key flavonoid genes [65].

During the synthesis of flavonoids, secondary metabolites are formed-anthocyanins and proanthocyanidins, pigmenting the vegetative and generative parts of the plant in red, blue or purple colors. The first works dedicated to the molecular genetic mechanisms inducing the formation of this group of pigments were carried out by Jende-Strid [56] and Meldgaard [57]. Employing a set of barley mutants, the researchers studied in detail the genes of the Ant group: Ant13, Ant17, Ant18, and Ant21. According to Jende-Strid, Ant13 is a regulatory gene that controls the work of structural genes involved in the synthesis of flavonoids [56]. Products of Ant13 act as transcription factors (TFs) of the Ant18 gene. In its turn, Ant18 encodes DFR (dihydroflavonol-4-reductase). The structural Ant17 gene $(3 \mathrm{H})$ encodes flavanone-3-hydroxylase (F3H) [56,57]. The Ant21 gene expression affects the formation of proanthocyanidins and anthocyanins [56]. Mutations in the Ant13, Ant17 [57], Ant18 and Ant21 genes cause the loss of pigmentation in plants [56]. These studies set the vector for further research into the molecular genetic mechanism responsible for the biosynthesis of plant polyphenols-anthocyanins.

By now, researchers have found and studied the sequences of structural genes for anthocyanin coloration in the vegetative and generative parts of $H$. vulgare plants. The gene families involved in the synthesis of flavonoid pigments have been identified for monocotyledonous and dicotyledonous plants. The main role in the synthesis of anthocyanin coloration is played by the enzymes: chalcone synthase [66], chalcone isomerase, [67-70] flavanone-3-hydroxylase $[57,61,71]$ flavonoid $3^{\prime}, 5^{\prime}$-hydroxylase [61], and dihydroflavonol4-reductase $[67,70]$. 
Regulatory genes encoding bHLH/Myc transcription factors are HvMyc1 (Ant2) and $H v M y c 2$. A genome-wide association analysis of two barley populations, with anthocyanin coloration (cv. 'Retriever') and without it (cv. 'Saffron'), revealed the Ant2 gene. The Ant2 gene is localized on chromosome $2 \mathrm{HL}$ and regulates the accumulation of purple pigments in the pericarp [72]. The HvMyc2 (4HL) gene provides for the formation of blue and pink anthocyanins in the aleurone layer [59,72]. Himi and Taketa (2015) identified the R2R3-MYB-encoding gene HvMpc1-H1 (Ant1), located on the short arm of chromosome $7 \mathrm{H}$, which determined the color of the barley kernel pericarp [73]. Strygina and Khlestkina (2019) identified the regulatory genes $H v M p c 1-H 2$ and $H v M p c 1-H 3$ that controlled the synthesis of anthocyanins and the color of the aleurone layer. Localization of genes was observed on 4HL [74]. The identification and analysis of the genes encoding TF of the WD40 family and determining the anthocyanin coloration of the kernel were carried out by Strygina et al. (2019). The HvWD40-1 gene was identified on the long arm of chromosome 6HL. The coding sequence for HvWD40-2, paralogous to HvWD40-1, was identified on the short arm of chromosome 6HS. The study suggests that it is HvWD40-2, together with the coding gene HvMpc1-H3 (family R2R3-Myb) and HvMyc2 (family bHLH), that forms the MBW regulatory complex which controls pigmentation of the aleurone layer in barley. No polymorphism was found in the studied genes [75].

Thus, the varied coloration in plants is induced by a large number of structural and regulatory genes responsible for the synthesis of flavonoid compounds. At present, thanks to the accomplishments of leading Russian and foreign researchers, the main components of the flavonoid formation mechanisms have been discovered, and data were obtained on the synthesis of anthocyanins in various tissues of barley. Further study of transcription factors, gene expression and their relationship with other physiological functions of plants will make it possible to develop new barley cultivars with desired properties. Such cultivars will be an integral part of the human diet and will serve as the basis for food security.

\subsection{Genes for the Biosynthesis of $\beta$-Glucans in Barley and Oats}

A characteristic feature of plants within the Poaceae family is the presence of $(1,3 ; 1,4)$ $\beta$-D-glucans ( $\beta$-glucans) in the plant cell walls. The structure of cereal $\beta$-glucans consists of unsubstituted unbranched polysaccharides that contain monomeric residues of $\beta-D-$ glucopyranosyl (Figure 2). The degree of polymerization of cereal $\beta$-glucans is about 1000 or more; with this in view, $(1,4)$-bonds are usually more common than $(1,3)$-bonds, the ratio of $(1,3)$-bonds to $(1,4)$-bonds being usually $1: 2$, with the exception of Hordeum vulgare L. and Avena sativa L. in which the (1.3) to (1.4) ratio is 2:1 or higher [76]. For example, this ratio in the water-soluble $\beta$-glucan of barley usually ranges from 2.2:1 to 2.6:1 [77]. Beta-glucans accumulate in the cell walls of growing vegetative tissues, occur in the secondary walls of the vascular network, and are the main components of the endosperm walls in cereal grains. They are a source of dietary and functional food. Thus, $\beta$-glucans of barley and oats affect the quality of flour, are able to reduce serum cholesterol levels in patients with hypercholesterolemia, and modulate the glycemic index in diabetic patients $[37,78]$.

Synthases encoded by the extensive CESA (cellulose synthase), CSL (cellulose synthaselike) and GSL (glucan synthase-like) gene families are involved in the synthesis of most $\beta$-linked polysaccharides in the cell walls of plants belonging to the Poaceae family. The CESA genes encode cellulose synthases, [79] GSL genes encode $(1,3)-\beta$-D-glucan synthase (callose synthase), $[80,81]$ and CSL genes encode enzymes that synthesize various $\beta$-linked polysaccharides of non-cellulose origin. CSL genes are regarded as candidate genes for enzymes encoding $\beta$-glucans $[76,82,83]$. This gene family was subdivided into 8 gene groups designated CSLA to CSLH. The CSLF and CSLH groups were found only in cereals, $[82,84]$ and the CSLF group was identified as a candidate for genes encoding $\beta$-glucans in cereal crops $[78,85,86]$. While studying the rice genome, six OsCslF genes belonging to the CSLF group were identified on chromosome 7, next to the Bmy2 marker. The genes were designated as OsCslF1, OsCslF2, OsCslF3, OsCslF4, OsCslF8 and OsCslF9 [84,87]. Burton et al. [87] identified three markers ( $A d h 8, A B G 019$ and Bmy2) that are significantly asso- 
ciated with $\beta$-glucan regulation in barley. One of the three significant marker sequences showed homology with the CslF genes in rice [88]. Burton, et al. mapped the HvCslF genes for barley and showed that at least two of these genes are mapped in the region of barley chromosome $2 \mathrm{H}$ defined by the QTL of $(1,3 ; 1,4)-\beta$-glucan close to the Bmy 2 marker.

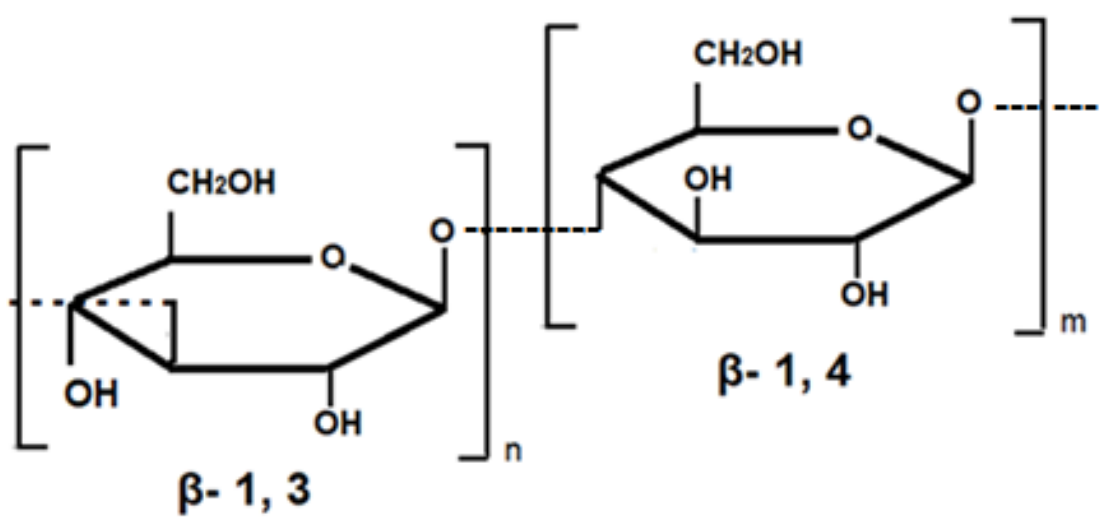

Figure 2. $\beta$-Glucans extracted from barley $(\beta-(1,3-1,4)$-D-glucan.

Using a genome-wide association analysis of three groups of elite oat cultivars, Fogarty et al. detected the AsCslF6 gene, encoding the synthesis of oat $\beta$-glucan synthase. Unlike diploid barley, oat is hexaploid and has three subgenomes: A, C and D. Subgenome-specific expression of homeologues A, C and D of the AsCslF6 gene showed that AsCslF6_C made the least contribution to $\beta$-glucan biosynthesis, while oat samples with a low $\beta$-glucan content demonstrated the highest input of the AsCslF6_C expression. At the same time, multiple homeologous copies of the AsCslF6_A and AsCslF6_D genes make a significant contribution to the common phenotype of samples with high $\beta$-glucan content [86].

Thus, although the structure and physicochemical properties of cell wall polysaccharides in barley and oat plants have been studied in detail, the enzymes and coding genes responsible for their synthesis remain underexplored. Further research into the genetic regulation of $\beta$-glucan biosynthesis would contribute to a promising trend in barley and oat breeding, since a high content of $\beta$-glucans in cultivars is important for functional food production.

\section{Study of Oat and Barley Accessions from the VIR Global Collection for the Content of Bioactive Components in Grain}

In the global germplasm collection of VIR, among the cultivated oats and barleys, there are numerous naked forms. The naked barley contains more than $13.56 \%$ of protein, which is superior to the hulled barley $(9.09 \%)$ in its nutritional value [89]. The effect of presowing treatment of oat seeds with succinic acid on the yield and quality of green biomass and grain was studied by VIR researchers [90]. Oat accessions were grown at Pushkin Experiment Base of VIR. The results showed that after treatment the quality and yield of green biomass and grain increased. The greatest increase in protein (by 5-8\%) and oil (by 10-13\%) was observed in cv. 'Astor' (the Netherlands). The maximum increase in seed yield after treatment was demonstrated by cvs. 'Hadmerslebener AG' (by 17-18\%) and 'Borrus' (by 9-13\%). Besides, it was noted that the presowing treatment of oat seeds with a solution of succinic acid contributed to a decrease in grain husk content [90]. EC Regulation 41/2009 included oats in the list of gluten-free ingredients safe for celiac disease (chronic intolerance to gluten, i.e., gluten proteins found mainly in wheat, rye and barley kernels), provided that the gluten content in the kernels should not exceed 20 ppm. [91]. The research carried out at VIR showed an important role of oat as a substitute for wheat in the gluten-free nutrition (diet) [92,93].

Using a combined HPLC and LC-MS analysis, comprehensive data on the total content and composition of avenanthramides were obtained for 120 accessions of cultivated oat and 32 of wild oats from the VIR global collection. An accession of the wild hexaploid species 
A. sterilis L. had the highest total content of avenanthramides in its grain $(1825 \mathrm{mg} / \mathrm{kg})$, and among the cultivated oat accessions the highest content $(407 \mathrm{mg} / \mathrm{kg})$ was observed in the naked cultivar 'Numbat' (Australia) (Table 2) [94].

Table 2. Content of avenanthramides in oat cultivars [94].

\begin{tabular}{|c|c|c|c|c|c|c|}
\hline \multirow{2}{*}{ VIR Catalogue No. } & \multirow{2}{*}{ Name of Cultivar } & \multirow{2}{*}{ Origin } & \multicolumn{4}{|c|}{ Content of Avenanthramides, mg/kg } \\
\hline & & & I & II & III & Average \\
\hline 14787 & Privet & RF, Moscow reg. & 23.46 & 36.92 & 30.39 & 30.26 \\
\hline 15277 & Bulanyi & RF, Moscow reg. & 8.28 & 13.06 & 7.31 & 9.55 \\
\hline 15187 & Eklips & RF, Kirov reg. & 92.60 & 121.67 & 144.32 & 119.53 \\
\hline 14648 & Argamak & RF, Kirov reg. & 5.38 & 6.60 & 6.11 & 6.03 \\
\hline 14857 & Krechet & RF, Kirov reg. & 20.27 & 19.91 & 29.90 & 23.36 \\
\hline 15068 & Konkur & RF, Ul'yanovsk reg. & 54.32 & 53.76 & 50.49 & 52.86 \\
\hline 14960 & Vyatskii * & RF, Kirov reg. & 214.10 & 169.50 & 261.20 & 214.93 \\
\hline 15275 & Persheron * & RF, Kirov reg. & 62.35 & 68.82 & 54.41 & 61.86 \\
\hline 15067 & Golets * & RF, Krasnoyask reg. & 77.62 & 82.14 & 79.24 & 79.67 \\
\hline 15067 & Levsha * & RF, Kemerovo reg. & 59.81 & 72.77 & 67.65 & 66.74 \\
\hline 15115 & Aldan * & RF, Kemerovo reg. & 60.54 & 83.74 & 56.44 & 66.91 \\
\hline 15116 & Murom * & RF, Kemerovo reg. & 138.98 & 170.54 & 200.71 & 170.08 \\
\hline 15117 & Pomor * & RF, Kemerovo reg. & 43.40 & 46.82 & 46.00 & 45.40 \\
\hline 15183 & Taidon * & RF, Kemerovo reg. & 140.20 & 165.76 & 122.96 & 142.97 \\
\hline 14851 & Numbat* & Australia & 358.87 & 460.00 & 403.78 & 407.55 \\
\hline
\end{tabular}

*-naked cultivars.

The study of the mineral composition of various oat varieties from the VIR collection is presented in publications [28,95]. The ranges of micronutrient content in oat grain were as follows: $19-37 \mathrm{mg} / \mathrm{kg}$ of $\mathrm{Fe}, 10-70$ of $\mathrm{Zn}$, and 3.5-9.9 of Mn, i.e., 7.0-fold variation in $\mathrm{Zn}$ and almost 3-fold variation in Mn were observed [95]. It was shown that such oat accessions as cvs. 'Boog', 'Circle', 'Vladyka' and 'Gavrosh' contained the highest amounts of $\mathrm{Fe}, \mathrm{Mn}$ and $\mathrm{Zn}$ [28]. The ranges of micronutrient content in barley grain were as follows: 24-79 mg/kg of Fe, 6-33 of Zn, and 7-21 of Mn. Thus, barley genotypes demonstrated a 3-5.5-fold variation in the content of $\mathrm{Fe}, \mathrm{Zn}$ and $\mathrm{Mn}$, while genotypic variations in seed micronutrients among wheat and rye cultivars were relatively small (1.5-2 times) [95]. Further search for cultivars rich in mineral composition seems to be an important task in the development of FFP and improvement of micronutrient-based diets.

A study aimed at identifying biochemical differences (metabolite markers) among naked and hulled oat cultivars for subsequent phenotyping the varietal gene pool of common oat was accomplished by Loskutov et al. [96]. The naked oat forms were found to have a higher content of hydroxybenzoic acids, and the hulled forms contained more phenols. It seems interesting to compare metabolomic patterns in the grain of wild species and cultivars from the VIR collection in order to identify potential sources of biochemical quality traits among wild oat species in the breeding process. Metabolites were detected, which content changed in the process of domestication or in which wild oat species differed from the cultivars of this crop. Among these compounds, along with such well-known components of healthy nutrition as oleic acid, glucose, fructose, etc., monoacylglycerols were identified: MAG 16:0, MAG-2 18:2 [97], tocopherols, sterols etc. Content of tocopherols and sterols was studied in oats accessions of VIR collection (Table 3). 
Table 3. Content of tocopherols and sterols in oat accessions.

\begin{tabular}{|c|c|c|c|c|}
\hline VIR Catalogue No. & Name of Cultivar & Origin & $\begin{array}{c}\text { Content of } \\
\text { Tocopherols, \% }\end{array}$ & Content of Sterols, \% \\
\hline 5184 & Local & Spain & 283 & 1.18 \\
\hline 11840 & Borrus & Germany & 184 & 1.00 \\
\hline 14648 & Argamak & RF, Kirov reg. & 189 & 0.64 \\
\hline 13780 & Skakun & RF, Moscow reg. & 180 & 0.64 \\
\hline 13918 & Kirovets & RF, Kirov reg. & 227 & 0.72 \\
\hline 13957 & Gunter & RF, Kirov reg. & 236 & 0.67 \\
\hline 14373 & Fakir & RF, Kirov reg. & 235 & 0.81 \\
\hline 14781 & Faust & RF, Kirov reg. & 195 & 0.77 \\
\hline 14857 & Krechet & RF, Kirov reg. & 149 & 0.61 \\
\hline 15177 & Derbi & RF, Ulaynovsk reg. & 169 & 0.62 \\
\hline 15180 & Piruet & RF, Ulaynovsk reg. & 167 & 0.64 \\
\hline 1931 & Local * & China & 223 & 0.74 \\
\hline 2472 & Local * & Mongolia & 415 & 0.97 \\
\hline 8317 & Local * & China & 106 & 0.85 \\
\hline
\end{tabular}

The amino acids content was higher and the content of fatty acid was lower in cultivated species compared to wild ones. The $\mathrm{AB}$ genome tetraploid wild species were characterized by improved values of fatty and organic acids, sterols, polyhydric alcohols and monosaccharides, but the maximum content of total sugars was found for genome $\mathrm{C}$ diploids wild species. However, most of parameters studied were minimum for wild tetraploid species with the AC genome. (Table 4) [97].

Table 4. Biochemical characteristics of caryopsis of wild and cultivated oats with different genomes (mg/100 g) [97].

\begin{tabular}{|c|c|c|c|c|c|c|c|}
\hline \multirow{2}{*}{ Name/Genomes } & \multicolumn{6}{|c|}{ Wild Oats } & \multirow{2}{*}{$\frac{\text { Cultivated Oats }}{\text { ACD }}$} \\
\hline & $\mathrm{C}$ & $\mathbf{A}$ & $\overline{A B}$ & AC & CD & ACD & \\
\hline Amino acids & $61.3 \pm 0.03$ & $67.5 \pm 0.05$ & $45.8 \pm 0.02$ & $19.3 \pm 0.01$ & $41.1 \pm 0.02$ & $30.4 \pm 0.02$ & $75.80 \pm 0.04$ \\
\hline Fatty acids & $1058.8 \pm 0.11$ & $603.6 \pm 0.08$ & $1040.6 \pm 0.10$ & $412.0 \pm 0.04$ & $656.1 \pm 0.07$ & $981.5 \pm 0.10$ & $494.00 \pm 0.10$ \\
\hline Sterols & $7.4 \pm 0.00$ & $13.6 \pm 0.01$ & $25.0 \pm 0.01$ & $13.5 \pm 0.01$ & $25.7 \pm 0.01$ & $26.4 \pm 0.02$ & $16.40 \pm 0.01$ \\
\hline Organic acids & $99.6 \pm 0.05$ & $126.5 \pm 0.08$ & $167.4 \pm 0.08$ & $37.1 \pm 0.02$ & $115.7 \pm 0.06$ & $108.8 \pm 0.07$ & $49.90 \pm 0.02$ \\
\hline $\begin{array}{l}\text { Polyhydric } \\
\text { alcohols }\end{array}$ & $370.3 \pm 0.11$ & $343.2 \pm 0.10$ & $342.4 \pm 0.10$ & $91.7 \pm 0.03$ & $171.3 \pm 0.05$ & $312.1 \pm 0.09$ & $189.90 \pm 0.09$ \\
\hline Monosaccharides & $1194.6 \pm 0.08$ & $1159.1 \pm 0.08$ & $1429.5 \pm 0.07$ & $358.3 \pm 0.02$ & $329.8 \pm 0.04$ & $1217.4 \pm 0.08$ & $901.50 \pm 0.09$ \\
\hline Disaccharides & $6943.7 \pm 0.14$ & $2243.1 \pm 0.05$ & $1588.0 \pm 0.03$ & $4979.1 \pm 0.10$ & $7424.2 \pm 0.15$ & $1448.4 \pm 0.03$ & $2361.40 \pm 0.09$ \\
\hline Total sugars & $8138.3 \pm 0.10$ & $3402.2 \pm 0.05$ & $3017.5 \pm 0.04$ & $5337.4 \pm 0.06$ & $7754.1 \pm 0.09$ & $2665.8 \pm 0.04$ & $3262.90 \pm 0.09$ \\
\hline
\end{tabular}

The content of $\beta$-glucans in barley grain is determined by both the plant genotype and the growing conditions [98-100]. Some authors believe that the genotype is of decisive importance, [101,102] while others favor the environmental conditions [103,104]. All biochemical parameters of the caryopsis depend on the growing conditions, but the content of protein, oil and other components, largely depends on the genotype and variety. At the same time, the content of $\beta$-glucans is more variable depending on the genotype and variety of the grain, compared to other biochemical parameters. Apparently, the content of $\beta$-glucans in naked forms of oats and barley is significantly higher than in hulled varieties. Also, the content of $\beta$-glucans in two-row barley varieties is higher than in six-row ones, but the waxy naked grain contains the largest amount of soluble $\beta$-glucans, this also depends on the color of the grain hulls. There is a persistent positive or persistent negative relationship between different indicators of grain and $\beta$-glucans, such as oil, yield, nature 
and weight of 1000 grains (unpublished data). A study of 33 cultivars and lines of barley in two arid areas in the United States showed that the variability in the $\beta$-glucans content in grain depended on the genotype to an extent of 51\% [102] to 66\% [104]. At the same time, the effect of environmental conditions on protein content in grain amounted to $69 \%$, and on the yield and test weight of grain to 83 and 70\%, respectively [102]. A study of 9 cultivars of barley and 10 of oats ascertained that varietal differences in the content of $\beta$-glucans persisted over the years [101]. It was shown that the phase of plant development also affected the $\beta$-glucan content in grain. The amount of $\beta$-glucans was observed to gradually increase in the process of grain development and reach a plateau or decrease during the maturation period [105]. Currently, there are conflicting data on the relationship between the accumulation of $\beta$-glucans in barley grain and the values of 1000 grain weight, protein and starch content $[100,106]$. Some authors see no interrelation between these features, while others point to a positive correlation. When studying the content of $\beta$-glucans in the grain of cultivated six-row and two-row barleys, no differences were found between these groups of cultivars [99]. Contradictory data were also obtained by the studies of naked and hulled barley cultivars. Some authors did not reveal significant differences between these forms, [106,107] while others found that the naked barley had a higher content of $\beta$-glucans than the hulled one $[99,108]$. At the same time, a group of Tibetan naked barleys was found to have the highest content of $\beta$-glucans in their grain [98].

VIR has all the possibilities (genetic sources and donors, direct and indirect methods for assessing grain material, etc.) to develop barley cultivars with the following properties: low gluten content (the first high-yielding accessions of cultivars capable of diversifying the diet of celiac patients were obtained through breeding, ); increased or decreased $\beta$-glucan content; low phytin content or high phytinase activity; and high content of anthocyanidins (e.g., with purple-colored grain) [109].

Protein content is one of the important quality features of both feed and food barleys. Many years of research have shown that the protein content in grain is determined by the genotype, despite the phenotypic variability of the trait. High productive with high-protein content forms were identified among both naked and hulled accessions of barley [110].

A strong impact on the quality of grain is exerted by diseases, therefore the breeding for quality is closely linked with the breeding for disease resistance. The most promising, cost-effective and safe way to reduce grain infestation is to develop cultivars possessing genetic resistance. One of the most widespread cereal crop diseases is Fusarium ear blight caused by a set of fungal species within the genus Fusarium [111]. Especially dangerous is the contaminated grain, because during the life cycle of Fusarium fungi it accumulates secondary fungal metabolites-mycotoxins. Secondary metabolites of this group of fungi have a negative effect on the quality of the produced grain and can cause severe intoxications in farm animals and humans. Despite the widespread incidence of Fusarium in Russia, practically no breeding efforts are being made to develop resistance to this dangerous disease in barley. According to the results of a long-term assessment of 60 local varieties, improved cultivars and lines of barley from the Far East and Siberia, 15 modern cultivars and breeding lines of barley from Krasnoyarsk and Primorsky Territories, and 11 cultivars approved for cultivation in the northwest of Russia, 14 accessions highly resistant to Fusarium blight were identified. Five of them are naked barley forms (k-2946, k-11070, k-11073, k-11076 and k-11082); they yield large grain, but are prone to lodging and susceptible to powdery mildew $[112,113]$. The genotype of the host plant also has a significant effect on the accumulation of mycotoxins. It was found that there are no cereal crop cultivars immune to Fusarium fungi; however, differences in resistance have been observed. Currently, there are several types of resistance to Fusarium ear blight (FEB) in cereals: (1) resistance to the penetration of the pathogen; (2) resistance to its dispersal along the ear; (3) seed resistance to infection; (4) tolerance, and (5) the ability to accumulate or degrade toxins [114,115]. The so-called "5th type of resistance" (the ability to accumulate/degrade toxins) affects the final content of toxins and makes it possible to obtain relatively "clean" grain, even under sufficiently high levels of infection. The study 
of six barley cultivars after artificial inoculation showed that type 4 resistance in barley is associated with type 3 resistance. Resistance to toxin accumulation (called type 5 resistance) is independent of all other types of resistance, while a high $\beta$-glucan content in grain was shown to promote type 5 resistance [116].

Thus, the existing global inter- and interspecific, botanical and genetic diversity of oats and barley in the VIR collection is continuously studied for the content of bioactive components in grain, necessary for the development of functional food products.

\section{Conclusions}

Studying plant genetic resources and the processes of biosynthesis of bioactive compounds requires constant improvement of methodological and theoretical approaches. Along with the progress achieved in understanding the role of individual compounds in human life activity, the knowledge about the huge number of compounds serving as sources of functional nutrition required for the normal functioning of the organism is increasing. Therefore, it is necessary to analyze the basic nutritional values of most cereal crops, including oats and barley. By now, the structure and physicochemical properties of cell wall polysaccharides in barley and oat plants have been studied. The main components in the flavonoid formation mechanisms have been discovered, and data on the synthesis of anthocyanins in various tissues of barley have been obtained. However, the enzymes and coding genes responsible for the synthesis of $\beta$-glucans and plant polyphenols remain underexplored. Further studies on transcription factors of gene expression and their relationship with other physiological functions of plants will enable breeders to develop new cereals cultivars with desired properties. Such cultivars will be an integral part of the human diet and serve as the basis for food security in every country.

Author Contributions: Conceptualization: N.A.S., I.G.L., T.V.S., V.S.P., O.N.K., A.V.K.; writing N.A.S., I.G.L., T.V.S., V.S.P., O.N.K. All authors have read and agreed to the published version of the manuscript.

Funding: The article was made with the support of the Ministry of Science and Higher Education of the Russian Federation under agreement No. 075-15-2020-911 date 16.11.2020 on providing a grant in the form of subsidies from the Federal budget of the Russian Federation. The grant was provided for state support for the creation and development of a World-class Scientific Center "Agrotechnologies for the Future".

Conflicts of Interest: The authors declare no conflict of interest.

\section{References}

1. Nikberg, I.I. Functional products in the structure of modern nutrition. Int. J. Endocrinol. 2011, 6, 64-69. (In Russian)

2. Functional Foods Market Size, Share \& Trends Analysis Report by Ingredient (Carotenoids, Prebiotics \& Probiotics, Fatty Acids, Dietary Fibers), by Product, by Application, and Segment Forecasts, 2019-2025. Available online: https:/ /www.researchandmarkets. com/reports / 4764576/functional-foods-market-size-share-and-trends (accessed on 28 January 2021).

3. Kornen, N.N.; Viktorova, E.P.; Evdokimova, O.V. Methodological approaches to the creation of healthy food. Nutr. Issues 2015, 84, 95-99. (In Russian)

4. Cheryl, G.F.; Sachin, K.S.; Arya, S.S. Cereal based functional beverages: A review. Microbiol. Biotechnol. Food Sci. Fernandesetal 2018, 8, 914-919. [CrossRef]

5. Aslam, H.; Green, J.; Jacka, F.N.; Collier, F.; Berk, M.; Pasco, J.; Samantha, L.D. Fermented foods, the gut and mental health: A mechanistic overview with implications for depression and anxiety. Nutr. Neurosci. 2020, 23, 659-671. [CrossRef]

6. Popov, V.S.; Grigoriev, S.V.; Illarionova, K.V.; Shelenga, T.V. Fatty acid composition of hemp and cotton oils and the prospects of their use in the food industry and functional nutrition. Agrar. Russ. 2019, 8, 9-15. (In Russian) [CrossRef]

7. Dydykin, A.S.; Ustinova, A.V.; Derevitskaya, O.K.; Aslanova, M.A.; Volovik, E.L. Functional meat and vegetable products using enriched vegetables. Food Ind. 2011, 8, 26-27. (In Russian)

8. Popov, V.S.; Sergeeva, S.S.; Barsukova, N.V. Functional and technological properties of oat grain and a promising range of food products based on it. Bull. Technol. Univ. 2016, 16, 147-152. (In Russian)

9. Koshevoy, O.S.; Fudina, E.V. Food security is the basis for ensuring economic security. News High. Educ. Inst. Volga Reg. 2015, 4, 188-196. (In Russian)

10. Kayshev, V.G.; Seregin, S.N. Functional food products: The basis for disease prevention, health promotion and active longevity. Food Ind. 2017, 7, 8-14. (In Russian) 
11. Matveeva, T.V.; Koryachkina, S.Y. Flour Confectionery for Functional Purposes. Scientific Bases, Technologies, Recipes; FGOU VPO "State University-Educational, Research and Production Complex": Orel, Russia, 2011; p. 358. ISBN 978-5-93932-312-3. (In Russian)

12. Marklinder, I.; Johansson, L.; Haglund, A.; Nagel-Held, B.; Seibel, W. Effects of Flour from Different Barley Varieties on Barley Sour Dough Bread. Food Qual. Prefer. 1996, 7, 275-284. [CrossRef]

13. Rico, D.; Peñas, E.; García, M.C.; Martínez-Villaluenga, C.; Rai, D.K.; Birsan, R.I.; Frias, J.; Martín-Diana, A.B. Sprouted barley flour as a nutritious and functional ingredient. Foods 2020, 9, 296. [CrossRef]

14. Valevskaya, L.; Dzyuba, N.; Bunyak, E.; Evdokimova, G. The meaning of grain cultures in healthy food. Sci. Eur. 2017, 18, 71-73.

15. Konuklar, G.; Inglett, G.E.; Warner, K.; Carriere, C.J. Use of a $\beta$-glucan hydrocolloidal suspension in the manufacture of low-fat Cheddar cheeses: Textural properties by instrumental methods and sensory panels. Food Hydrocoll. 2004, 18, 535-545. [CrossRef]

16. Khomyakova, N.V. Oat bread-A concentrate of benefits and taste. Rus Bakery. 2007, 2, 36.

17. Gormley, T.R.; Morrissey, A. A note on the evaluation of wheaten breads containing oat flour or oat flakes. Ir. J. Agric. Food Res. 1993, 32, 205-209.

18. Saarela, M.; Virkajärvi, I.; Nohynek, L.; Vaari, A.; Mättö, J. Fibres as carriers for Lactobacillus rhamnosus during freeze-drying and storage in apple juice and chocolatecoated breakfast cereals. Int. J. Food Microbiol. 2006, 112, 171-178. [CrossRef] [PubMed]

19. Angelov, A.; Gotcheva, V.; Kuncheva, R.; Hristozova, T. Development of a new oat-based probiotic drink. Int. J. Food Microbiol. 2006, 112, 75-80. [CrossRef] [PubMed]

20. Selezneva, I.S. Influence of $\beta$-glucan from oats on the properties of low-fat yogurt. Sci. J. NRU ITMO Ser. Process. Appar. Food Prod. 2019, 4, 111-116.

21. Sidhu, J.S.; Kabir, Y.; Huffman, F.G. Functional foods from cereal grains. Int. J. Food Prop. 2007, 10, 231-244. [CrossRef]

22. Gorash, A.; Armoniene, R.; Fetch, J.M.; Liatukas, Z.; Danyte, V. Aspects in oat breeding: Nutrition quality, nakedness and disease resistance, challenges and perspectives: Review article. Ann. Appl. Biol. 2017, 171, 281-302. [CrossRef]

23. Welch, R.W. Nutrient composition and nutritional quality of oats and comparisons with other cereals. In Oats: Chemistry and Technology, 2nd ed.; American Association of Cereal Chemists Inc.: St. Paul, MN, USA, 2011; pp. 95-107. ISBN 9780128104521.

24. Shewry, P.R.; Piironen, V.; Lampi, A.M.; Nyström, L.; Li, L.; Rakszegi, M.; Fraś, A.; Boros, D.; Gebruers, K.; Courtin, C.M.; et al. Phytochemical and fiber components in oat varieties in the health grain diversity screen. J. Agric. Food Chem. 2008, 56, 9777-9784. [CrossRef] [PubMed]

25. Loskutov, I.G.; Kovaleva, O.N.; Blinova, E.V. Genetic diversity barley and oats of N.I. Vavilov All-Russian Research Institute of Plant Industry collections for breeding. Proc. Latv. Acad. Sci. Sect. B Nat. Exact Appl. Sci. 2012, 66, 20-30. [CrossRef]

26. Loskutov, I.G.; Rines, H.W. Avena L. In Wild Crop Relatives: Genomic and Breeding Resources, Cereals; Kole, C., Ed.; Springer: Berlin/Heidelberg, Germany; Institute of Nutraceutical Research, Clemson University: Clemson, SC, USA, 2011 ; pp. 109-183. ISBN 978-3-642-14228-4.

27. Lapveteläinen, A.; Aro, T. Protein composition and functionality of high-protein oat four derived from integrated starch ethanol process. Cereal Chem. 1994, 71, 133-139.

28. Bityutsky, N.P.; Loskutov, I.G.; Yakkonen, K.L.; Konarev, A.V.; Shelenga, T.V.; Khoreva, V.I.; Blinova, E.; Ryumin, A. Screening of Avena Sativa cultivars for iron, zinc, manganese, protein and oil content and fatty acid composition in whole grains. Cereal Res. Commun. 2020, 48, 87-94. [CrossRef]

29. Zhoua, M.; Robards, K.; Glennie-Holmes, M.; Helliwell, S. Oat Lipids. J. Am. Oil Chem. Soc. 1999, 76, 159-169. [CrossRef]

30. Loskutov, I.G. Oats (Avena L.)—Distribution, Taxonomy, Evolution and Breeding Value; VIR: Saint-Petersburg, Russia, $2007 ;$ p. 336. (In Russian)

31. Batalova, G.A.; Krasilnikov, V.N.; Popov, V.S.; Safonova, E.E. Characteristics of the fatty acid composition of naked oats of Russian selection. In Proceedings of the IOP Conference Series: Earth and Environmental Science, St. Petersburg, Russia, 13-14 December 2018; IOP Publishing Ltd.: Bristol, UK, 2019; Volume 337, pp. 1-5.

32. Krasilnikov, V.N.; Batalova, G.A.; Popov, V.S.; Sergeeva, S.S. Fatty acid composition of lipids in naked oat grain of domestic varieties. Russ. Agric. Sci. 2018, 44, 406-408. [CrossRef]

33. Andreev, N.R.; Batalova, G.A.; Nosovskaya, L.P.; Adikaeva, L.V.; Goldstein, V.G.; Shevchenko, S.N. Evaluation of the technological properties of some cultivars of naked oats as a raw material for the production of starch. Legum. Cereal Crop. 2016, 1, 83-89. (In Russian)

34. Leonova, S.; Shelenga, T.; Hamberg, M.; Konarev, A.V.; Loskutov, I.G.; Carlsson, A.S. Analysis of oil composition in cultivars and wild species of oat (Avena sp.). J. Agric. Food Chem. 2008, 56, 7983-7991. [CrossRef]

35. Fincher, G.B.; Stone, B.A. Cell walls and their components in cereal grain technology. In Advances in Cereal Science and Technology; Pomeranz, Y., Ed.; American Association of Cereal Chemists Inc.: St. Paul, MN, USA, 1986; pp. 207-295. ISBN 978-0913250396.

36. Krasilnikov, V.N.; Gavrilyuk, I.P.; Batalova, G.A.; Afonin, D.V.; Popov, V.S.; Sergeeva, S.S.; Loskutov, I.G.; Gubareva, N.K. Dietary fiber and avenins of grain of naked varieties of oats of new selection. Int. Sci. Res. J. 2017, 1, 111-116. (In Russian) [CrossRef]

37. Wood, P.J.; Beer, M.U. Functional oat products. In Functional Foods. Biochemical \& Processing Aspects, 1st ed.; Mazza, G., Ed.; Technomic Publishing Co.: Lancaster, PA, USA, 1998; Volume 1, pp. 1-37. ISBN 9780367400415.

38. Wood, P.J.; Paton, D.; Siddiquil, R. Determination of beta-glucan in oats and barley. Cereal Chem. 1977, 54, 524-533.

39. Khoury, D.E.; Cuda, C.; Luhovyy, B.L.; Anderson, G.H. Beta Glucan: Health Benefits in Obesity and Metabolic Syndrome. J. Nutr. Metab. 2012, 2012, 851362. [CrossRef] 
40. Popov, V.S.; Krasilnikov, V.N.; Barsukova, N.V. Oat $\beta$-glucans in functional and therapeutic nutrition. Probl. Econ. Manag. Trade Ind. 2014, 2, 78-83. (In Russian)

41. Brownlee, I.A. The physiological roles of dietary fibre. Food Hydrocoll. 2011, 25, 238-250. [CrossRef]

42. Chang, H.C.; Huang, C.N.; Yeh, D.M.; Wang, S.J.; Peng, C.H.; Wang, C.J. Oat prevents obesity and abdominal fat distribution, and improves liver function in humans. Plant Foods Hum. Nutr. 2013, 68, 18-23. [CrossRef]

43. Harland, J. Authorised EU health claims for barley and oat beta-glucans. In Foods, Nutrients and Food Ingredients with Authorised EU Health Claims; Sadler, M.J., Ed.; Woodhead Publishing: Cambridge, UK, 2014; Volume 2, pp. 25-45. ISBN 978-0-85709-842-9.

44. Wood, P.J. Oat and rye $\beta$-glucan: Properties and function. Cereal Chem. 2010, 87, 315-330. [CrossRef]

45. Regand, A.; Chowdhury, Z.; Tosh, S.M.; Wolever, T.M.S.; Wood, P. The molecular weight, solubility and viscosity of oat beta-glucan affect human glycemic response by modifying starch digestibility. Food Chem. 2011, 129, 297-304. [CrossRef]

46. Kumar, K.; Chauhan, D.; Kumar, S.; Sharma, M.; Kaur, R.; Vyas, P. Barley: A potential source of functional food ingredients. In Proceedings of the National Seminar on Technological Interventions in Food Processing and Preservation, Rajasthan, India, 17 November 2017; Amity University: Jaipur, India, 2017; pp. 85-86.

47. Tiwari, P.K.; Sahu, R.K.; Sandey, K.K.; Tiwari, R.K. Importance of oats in human diet: A review. Bull. Environ. Pharmacol. Life Sci. 2017, 7, 125-130.

48. Gao, C.; Gao, Z.; Greenway, F.L.; Burton, H.J.; Johnson, W.D.; Keenan, M.J.; Enright, F.M.; Martin, R.J.; Chu, Y.; Zheng, J. Oat consumption reduced intestinal fat deposition and improved health span in Caenorhabditis elegans model. Nutr. Res. 2015, 35, 834-843. [CrossRef]

49. Thomas, M.; Kim, S.; Guo, W.; Collins, W.F.; Wise, M.L.; Meydani, M. High levels of avenanthramides in oat-based diet further suppress high fat diet-induced atherosclerosis in Ldlr-/- Mice. J. Agric. Food Chem. 2018, 66, 498-504. [CrossRef]

50. Hurtado-Fernández, E.; Gómez-Romero, M.; Carrasco-Pancorbo, A.; Fernández-Gutiérrez, A. Application and potential of capillary electroseparation methods to determine antioxidant phenolic compounds from plant food material. J. Pharm. Biomed. Anal. 2010, 53, 1130-1160. [CrossRef]

51. Zielinski, H.; Ciska, E.; Kozlowska, H. The cereal grains: Focus on vitamin E. Czech Food Sci. 2001, 19, 182-188. [CrossRef]

52. Polonskiy, V.I.; Loskutov, I.G.; Sumina, A.V. Breeding for antioxidant content in grain as a promising trend in obtaining healthy food products. Russ. J. Genet. Appl. Res. 2018, 22, 343-352. [CrossRef]

53. Makarenko, O.A.; Levitsky, A.P. Physiological functions of flavonoids in plants. Physiol. Biochem. Cultiv. Plants 2013, 45, 100-112. (In Russian)

54. Adzhieva, V.F.; Babak, O.G.; Shoeva, O.J.; Kilchevsky, A.V.; Khlestkina, E.K. Molecular genetic mechanisms of the formation of the color of fruits and seeds of plants. Russ. J. Genet. Appl. Res. 2015, 19, 561-573. [CrossRef]

55. Khlestkina, E.K. The adaptive role of flavonoids: Emphasis on cereals. Cereal Res. Commun. 2013, 41, 185-198. [CrossRef]

56. Jende-Strid, B. Gene-enzyme relations in the pathway of flavonoid biosynthesis in barley. Theor. Appl. Genet. 1991, 81, 668-674. [CrossRef] [PubMed]

57. Meldgaard, M. Expression of chalcone synthase, dihydroflavonol reductase, and flavanone-3-hydroxylase in mutants of barley deficient in anthocyanin and proanthocyanidin biosynthesis. Theor. Appl. Genet. 1992, 83, 695-706. [CrossRef]

58. Dubcovsky, J.; Luo, M.C.; Zhong, G.Y.; Bransteitter, R.; Desai, A.; Kilian, A.; Kleinhofs, A.; Dvorak, J. Genetic map of diploid wheat, Triticum monococcum L., and its comparison with maps of Hordeum vulgare L. Genetics 1996, 143, 983-999. [CrossRef]

59. Strygina, K.V.; Börner, A.; Khlestkina, E.K. Identification and characterization of regulatory network components for anthocyanin synthesis in barley aleurone. BMC Plant Biol. 2017, 17, 184. [CrossRef]

60. Shoeva, O.Y.; Strygina, K.V.; Khlestkina, E.K. Genes that control the synthesis of flavonoid and melanin pigments in barley. Russ. J. Genet. Appl. Res. 2018, 22, 333-342. [CrossRef]

61. Vikhorev, A.V.; Strygina, K.V.; Khlestkina, E.K. Duplicated flavonoid 3'-hydroxylase and flavonoid 3', $5^{\prime}$-hydroxylase genes in barley genome. PeerJ 2019, 7, e6266. [CrossRef]

62. Khlestkina, E.K.; Shoeva, O.Y.; Gordeeva, E.I. Flavonoid biosynthesis genes in wheat. Russ. J. Genet. Appl. Res. 2014, 18, 784-796. [CrossRef]

63. Shoeva, O.Y.; Khlestkina, E.K.; Berges, H.; Salina, E.A. The homeologous encoding chalcone-flavanone isomerase in Triticum aestivum L.: Structural characterization and expression in different parts of wheat plant. Gene 2014, 538, 334-341. [CrossRef] [PubMed]

64. Karre, S.; Kumar, A.; Yogendra, K.; Kage, U.; Kushalappa, A.; Charron, J.-B. HvWRKY23 regulates flavonoid glycoside and hydroxycinnamic acid amide biosynthetic genes in barley to combat Fusarium head blight. Plant Mol. Biol. 2019, 100, 591-605. [CrossRef] [PubMed]

65. Karre, S.; Kumar, A.; Dhokane, D.; Kushalappa, A.C. Metabolo-transcriptome profiling of barley reveals induction of chitin elicitor receptor kinase gene (HvCERK1) conferring resistance against Fusarium graminearum. Plant Mol. Biol. 2017, 93, 247-267. [CrossRef] [PubMed]

66. Druka, A.; Kudrna, D.; Rostoks, N.; Brueggeman, R.; Wettstein, D.; Kleinhofs, A. Chalcone isomerase gene from rice (Oryza sativa) and barley (Hordeum vulgare): Physical, genetic and mutation mapping. Gene 2003, 302, 171-178. [CrossRef]

67. Kristiansen, K.N.; Rohde, W. Structure of the Hordeum vulgare gene encoding dihydroflavonol-4-reductase and molecular analysis of antl8 mutants blocked in flavonoid synthesis. Mol. Gen. Genet. 1991, 230, 49-59. [CrossRef] 
68. Christensen, A.B.; Gregersen, P.L.; Schröder, J.; Collinge, D.B. A chalcone synthase with an unusual substrate preference is expressed in barley leaves in response to UV light and pathogen attack. Plant Mol. Biol. 1998, 37, 849-857. [CrossRef]

69. Pecchioni, N.; Vale, G.; Toubia-Rahme, H.; Faccioli, P.; Terzi, V.; Delogu, G.; Fischbeck, G. Barley-Pyrenophora graminea interaction: QTL analysis and gene mapping. Plant Breed. 1999, 118, 29-35. [CrossRef]

70. Peukert, M.; Weise, S.; Röder, M.S.; Matthies, I.E. Development of SNP markers for genes of the phenylpropanoid pathway and their association to kernel and malting traits in barley. BMC Genet. 2013, 14, 97. [CrossRef]

71. Khlestkina, E.K.; Salina, E.A.; Matthies, I.E.; Leonova, I.N.; Börner, A.; Röder, M.S. Comparative molecular marker-based genetic mapping of flavanone 3-hydroxylase genes in wheat, rye and barley. Euphytica 2011, 179, 333-341. [CrossRef]

72. Cockram, J.; White, J.; Zuluaga, D.L.; Smith, D.; Comadran, J.; Macaulay, M.; Luo, Z.; Kearsey, M.J.; Werner, P.; Harrap, D.; et al Genome wide association mapping to candidate polymorphism resolution in the unsequenced barley genome. Proc. Natl. Acad. Sci. USA 2010, 107, 21611-21616. [CrossRef]

73. Himi, E.; Taketa, S. Isolation of candidate genes for the barley Ant1 and wheat Rc genes controlling anthocyanin pigmentation in different vegetative tissues. Mol. Genet. Genom. 2015, 290, 1287-1298. [CrossRef]

74. Strygina, K.V.; Khlestkina, E.K. Structural and functional divergence of the Mpc1 genes in wheat and barley. BMC Evol. Biol. 2019, 19, 90-99. [CrossRef]

75. Strygina, K.V.; Khlestkina, E.K. Structural and functional organization and evolution of the WD40 genes involved in the regulation of flavonoid biosynthesis in the Triticeae Tribe. Russ. J. Genet. 2019, 55, 1398-1405. [CrossRef]

76. Doblin, M.S.; Pettolino, F.A.; Wilson, S.M.; Campbell, R.; Burton, R.A.; Fincher, G.B.; Newbigin, E.; Bacic, A. A barley cellulose synthase-like CSLH gene mediates (1,3;1,4)- $\beta$-D-glucan synthesis in transgenic Arabidopsis. Proc. Natl. Acad. Sci. USA 2009, 106, 5996-6001. [CrossRef] [PubMed]

77. Fincher, G.B. Exploring the evolution of $(1,3 ; 1,4)-\beta-\mathrm{d}$-glucans in plant cell walls: Comparative genomics can help! Curr. Opin. Plant Biol. 2009, 12, 140-147. [CrossRef]

78. Buckeridge, M.S.; Rayon, C.; Urbanowicz, B.; Tiné, M.A.S.; Carpita, N.C. Mixed Linkage $(1 \rightarrow 3),(1 \rightarrow 4)-\beta$-D-Glucans of Grasses. Cereal Chem. J. 2004, 81, 115-127. [CrossRef]

79. Delmer, D.P. Cellulose biosynthesis: Exciting times for a difficult field of study. Annu. Rev. Plant Physiol. Plant Mol. Biol. 1999, 50, 245-276. [CrossRef] [PubMed]

80. Delaney, B.; Nicolosi, R.J.; Wilson, T.A.; Carlson, T.; Frazer, S.; Zheng, G.H.; Hess, R.; Ostergren, K.; Haworth, J.; Knutson, N. B-Glucan fractions from barley and oats are similarly antiatherogenic in hypercholesterolemic Syrian Golden Hamsters. J. Nutr. 2003, 133, 468-475. [CrossRef]

81. Li, J.; Burton, R.A.; Harvey, A.J.; Hrmova, M.; Wardak, A.Z.; Stone, B.A.; Fincher, G.B. Biochemical evidence linking a putative callose synthase gene with $(1 \rightarrow 3)$-beta-D-glucan biosynthesis in barley. Plant Mol. Biol. 2003, 53, 213-225. [CrossRef]

82. Richmond, T.A.; Somerville, C.R. The Cellulose Synthase Superfamily. Plant Physiol. 2000, 124, 495-498. [CrossRef]

83. Farrokhi, N.; Burton, R.A.; Brownfield, L.; Hrmova, M.; Wilson, S.M.; Bacic, A.; Fincher, G.B. Plant cell wall biosynthesis: Genetic, biochemical and functional genomics approaches to the identification of key genes. Plant Biotechnol. J. 2006, 4, 145-167. [CrossRef] [PubMed]

84. Hazen, S.P.; Scott-Craig, J.S.; Walton, J.D. Cellulose synthase-like genes of rice. Plant Physiol. 2002, 128, 336-340. [CrossRef]

85. Burton, R.A.; Collins, H.M.; Kibble, N.A.J.; Smith, J.A.; Shirley, N.J.; Jobling, S.A.; Henderson, M.; Singh, R.R.; Pettolino, F.; Wilson, S.M.; et al. Over-expression of specific $\mathrm{HvCslF}$ cellulose synthase-like genes in transgenic barley increases the levels of cell wall $(1,3 ; 1,4)-\beta$-d-glucans and alters their fine structure. Plant Biotechnol. J. 2011, 9, 117-135. [CrossRef] [PubMed]

86. Fogarty, M.C.; Smith, S.M.; Sheridan, J.L.; Hu, G.; Islamovic, E.; Reid, R.; Jackson, E.W.; Maughan, P.J.; Ames, N.P.; Jellen, E.N.; et al. Identification of mixed linkage $\beta$-glucan quantitative trait loci and evaluation of AsCslF6 homoeologs in hexaploid oat. Crop Sci. 2020, 60, 914-933. [CrossRef]

87. Burton, R.A.; Wilson, S.M.; Hrmova, M.; Harvey, A.J.; Shirley, N.J.; Medhurst, A.; Stone, B.A.; Newbigin, E.J.; Bacic, A.; Fincher, G.B. Cellulose synthase-like CslF genes mediate the synthesis of cell wall (1,3;1,4)- $\beta$-D-glucans. Science 2006, 311, 1940-1942. [CrossRef]

88. Newell, M.A.; Asoro, F.G.; Scott, M.P.; White, P.J.; Beavis, W.D.; Jannink, J.-L. Genome-wide association study for oat (Avena sativa L.) beta-glucan concentration using germplasm of worldwide origin. Theor. Appl. Genet. 2012, 125, 1687-1696. [CrossRef] [PubMed]

89. Yanova, M.A.; Tsuglenok, G.I.; Ivanova, T.S. The use of naked forms of barley and oats in food production. Bull. Krasgau 2012, 4, 203-205. (In Russian)

90. Nizova, G.K.; Yarosh, N.P. Influence of pre-sowing treatment of seeds with succinic acid on the quality of green mass and oat grain. Sci. Tech. Bull. N.I. Vavilov All-Russ. Res. Inst. Plant Ind. 1988, 184, 17. (In Russian)

91. Ballabio, C.; Uberti, F.; Manferdelli, S.; Vacca, E.; Boggini, G.; Redaelli, R.; Catassie, C.; Lionetti, E.; Peñas, E.; Restani, P. Molecular characterisation of 36 oat varieties and in vitro assessment of their suitability for coeliacs' diet. J. Cereal Sci. 2011, 54, 110-115. [CrossRef]

92. Gavrilyuk, I.P.; Gubareva, N.K.; Perchuk, I.N.; Loskutov, I.G.; Konarev, A.V.; Oreshko, L.S. The avenins and celiac disease. In Proceedings of the 3rd International Symposium on Gluten-Free Cereal Products and Beverages, Vienna, Austria, 12-14 June 2013; p. 15. 
93. Konarev, A.V.; Shelenga, T.V.; Perchuk, I.N.; Blinova, E.V.; Loskutov, I.G. Characteristics of the diversity of oats (Avena L.) from the collection of VIR-The initial material for breeding for resistance to fusarium. Agrar. Russ. 2015, 5, 1-10. (In Russian) [CrossRef]

94. Leonova, S.; Gnutikov, A.; Loskutov, I.; Blinova, E.; Gustafsson, K.E.; Olsson, O. Diversity of avenanthramide content in cultivated and wild oats. Proc. Appl. Bot. Genet. Breed. 2020, 181, 30-47. (In Russian) [CrossRef]

95. Bityutskii, N.; Yakkonen, K.; Loskutov, I. Content of iron, zinc and manganese in grains of Triticum aestivum, Secale cereale, Hordeum vulgare and Avena sativa cultivars registered in Russia. Genet. Resour. Crop Evol. 2017, 64, 1955-1961. [CrossRef]

96. Loskutov, I.G.; Shelenga, T.V.; Konarev, A.V.; Vargach, Y.I.; Porokhovinova, E.A.; Blinova, E.V.; Gnutikov, A.A.; Rodionov, A.V. Biochemical approach of structuring the variety diversity of the naked and covered forms of cultural oats (Avena Sativa L.). Ecol. Genet. 2020, 18, 27-41. (In Russian) [CrossRef]

97. Loskutov, I.G.; Shelenga, T.V.; Konarev, A.V.; Shavarda, A.L.; Blinova, E.V.; Dzubenko, N.I. The metabolomic approach to the comparative analysis of wild and cultivated species of oats (Avena L.). Russ. J. Genet. Appl. Res. 2016, 20, 636-642. [CrossRef]

98. Zhang, G.P.; Wang, J.M.; Chen, J.X. Analysis of $\beta$-glucan content in barley cultivars from different locations of China. Food Chem. 2002, 79, 251-254. [CrossRef]

99. Fastnaught, C.E.; Berglund, P.T.; Holm, E.T.; Fox, G.J. Genetic and environmental variation in $\beta$-glucan content and quality parameters of barley for food. Crop Sci. 1996, 36, 941-946. [CrossRef]

100. Yalcin, E.; Celik, S.; Akar, T.; Sayim, I.; Koksel, H. Effects of genotype and environment on $\beta$-glucan and dietary fibre contents of hull-less barleys grown in Turkey. Food Chem. 2007, 101, 171-176. [CrossRef]

101. Lee, C.J.; Horsley, R.D.; Manthey, F.A.; Schwarz, P.B. Comparison of $\beta$-glucan content of barley and oat. Cereal Chem. 1997, 74, 571-575. [CrossRef]

102. Hang, A.; Obert, D.; Gironella, A.I.N.; Burton, C.S. Barley amylase and $\beta$-glucan: Their relationships to protein, agronomic traits, and environmental factors. Crop Sci. 2007, 47, 1754-1760. [CrossRef]

103. Zhang, G.; Chen, J.; Wang, J.; Ding, S. Cultivar and environmental effects on (1-3, 1-4)- $\beta$-glucan and protein content in malting barley. J. Cereal Sci. 2001, 34, 295-301. [CrossRef]

104. Rey, J.I.; Hayes, P.M.; Petrie, S.E.; Corey, A.; Flowers, M.; Ohm, J.B.; Ong, C.; Rhinhart, K.; Ross, A.S. Production of dryland barley for human food: Quality and agronomic performance. Crop Sci. 2009, 49, 347-355. [CrossRef]

105. Aman, P.; Graham, H.; Tilley, A.-C. Content and solubility of mixed-linked (1-3;1-4)- $\beta$-glucan in barley and oats during kernel development and storage. J. Cereal Sci. 1989, 10, 45-50. [CrossRef]

106. Griffey, C.; Brooks, W.; Kurantz, M.; Thomason, W.; Taylor, F.; Obert, D.; Morea, R.; Flores, R.; Sohn, M.; Hicks, K. Grain composition of Virginia winter barley and implications for use in feed, food, and biofuels production. J. Cereal Sci. 2010, 51, 41-49. [CrossRef]

107. Knutsen, S.H.; Holtekjilen, A.K. Preparation and analysis of dietary fiber constituents in whole grain from hulled and hull-less barley. Food Chem. 2007, 102, 707-715. [CrossRef]

108. Huth, M.; Dongowski, G.; Gebhart, E.; Flamme, W. Functional properties of dietary fibre enriched exudates from barley. J. Cereal Sci. 2002, 32, 115-117. [CrossRef]

109. Konarev, A.V.; Loskutov, I.G.; Shelenga, T.V.; Khoreva, V.I.; Konarev, A.V. Plant genetic resources-An inexhaustible source of healthy food. Agrar. Russ. 2019, 2, 38-48. (In Russian) [CrossRef]

110. Lukyanova, M.V.; Trofimovskaya, A.Y.; Gudkova, G.N.; Terentyeva, I.A.; Yarosh, N.P. Cultural Flora of the USSR: Barley; Agropromizdat: Leningrad, Russia, 1990; Volume 3, p. 421. (In Russian)

111. Gagkaeva, T.Y.; Gavrilova, O.P.; Levitin, M.M.; Novozhilov, K.V. Fusariosis of grain crops. Suppl. J. Plant Prot. Q. 2011, 5, 69-120. (In Russian)

112. Gagkaeva, T.Y.; Levitin, M.M.; Zuev, E.V.; Terentjeva, I.A. Evaluation of genetic resources of wheat and barley from Far East of Russia for resistance to Fusarium head blight. J. Appl. Genet. 2002, 43A, 229-236.

113. Gagkaeva, T.Y.; Gavrilova, O.P. Fusarium head and grain of barley. Work. Appl. Bot. Breed. 2009, 165, 39-44. (In Russian)

114. Mesterhasy, A. Types and components resistance to Fusarium head blight of wheat. Plant Breed. 1995, 114, 377-386. [CrossRef]

115. Miller, J.D.; Young, J.C.; Sampson, R.D. Deoxynivalenol and Fusarium head blight resistance in spring cereals. J. Phytopathol. 1985, 113, 359-367. [CrossRef]

116. Martin, C.; Schöneberg, T.; Vogelgsang, S.; Morisoli, R.; Bertossa, M.; Mauch-Mani, B.; Mascher, F. Resistance against Fusarium graminearum and the relationship to $\beta$-glucan content in barley grains. Eur. J. Plant Pathol. 2018, 152, 621-634. [CrossRef] 